\title{
ANTIBIOTIC CONSUMPTION AT A PEDIATRIC WARD AT A PUBLIC HOSPITAL IN INDONESIA
}

\author{
FAUNA HERAWATI ${ }^{1,2 *}$, MUHAMAD SATRIA MANDALA PUA UPA ${ }^{1}$, RIKA YULIA ${ }^{1}$, RETNOSARI ANDRAJATI ${ }^{2}$
}

${ }^{1}$ Department of Clinical and Community Pharmacy, Faculty of Pharmacy, Universitas Surabaya, Jalan Raya Kalirungkut, Surabaya 60293, Indonesia. ${ }^{2}$ Department of Pharmacology and Clinical Pharmacy, Faculty of Pharmacy, Universitas Indonesia, Depok, Indonesia. Email: fauna@staff.ubaya.ac.id

Received: 02 April 2019, Revised and Accepted: 11 June 2019

ABSTRACT

Objective: The aims of the study are to describe how antibiotics were used in a pediatric ward and to observe how they were prescribed for infectious diarrheas of bacterial origin indication. Diarrhea or acute gastroenteritis is one of the most common infection diagnoses observed among the hospitalized children. Rehydration therapy is the key treatment for children with diarrhea. With the zinc supplement, the duration of the hospital stay can be reduced. Thus, the decision whether the local or regional health authorities need to provide an antibiotic treatment depends on the etiology of the disease, the patient's nutritional history and immunological status, and eventually, the severity of the disease. Good anamneses and diagnoses are essential to decide whether antibiotic treatment is required.

Methods: The observation in this study consists of two phases. The first-phase observation was taken from the diagnosis and the number of antibiotics used in 2016 retrospectively calculated from each of the patients' medical records. Meanwhile, the second phase descriptive observation was prospectively drawn from the stool culture and the number of antibiotics prescribed to 21 inpatient diarrhea children between May 2017 and December 2017. The amount of antibiotic consumption was administered based on defined daily dose (DDD) and days of therapy (DOT)

Results: In 2016, 56\% (828/1476) of the patients received antibiotic prescriptions. On average, the DDD per 100 bed-days was 45.57. In the prospective study, six of 21 patients with diarrhea were prescribed antibiotics intravenously. The DOT was 3.5 days and the DDD for these patients was $12.10 / 100$ bed-days.

Conclusion: There was a high consumption rate of antibiotics which was not indicated in each patient's etiology of diarrhea in the hospital during the period. Thus, the recommendation is to encourage health authorities to judiciously prescribe antibiotics according to the guidelines.

Keywords: Antibiotic prescription, Days of therapy, Defined daily dose, Diarrhea, Pediatrics.

(C) 2019 The Authors. Published by Innovare Academic Sciences Pvt Ltd. This is an open access article under the CC BY license (http://creativecommons. org/licenses/by/4. 0/) DOI: http://dx.doi.org/10.22159/ajpcr.2019.v12i8.33339

\section{INTRODUCTION}

Children are admitted to hospitals mostly due to diagnoses of either infectious or non-infectious diseases. This study, however, focuses on the diagnoses of infectious diseases among which are urinary tract infection, acute meningitis, community-acquired pneumonia, fever without a localized source, and diarrhea (acute gastroenteritis). These infectious diseases are also the most common indications for antibiotics in hospitalized children [1-3]. Diarrhea or acute gastroenteritis is one of the most common infectious diagnoses seen in hospitalized children. Typically, antibiotics are not for routine use to treat gastroenteritis, except diarrhea triggered by Shigella, Vibrio cholera, or parasites [4]. The percentage of the patients who receive antibiotics should correlate with the percentage of the diagnoses of the infection. The higher number of antibiotic use could be a predictor of a higher infection prevalence. Unfortunately, there is excessive antibiotic use without any indications of infection [5]. Inappropriate use of antibiotics will increase the incidence of bacterial resistance to antibiotics [6-8]. One of the antimicrobial stewardship programs the goal of the Danish Ministry of Health is to reduce antibiotic consumption by $10 \%$ in 4 years' time with the defined daily dose (DDD)/100 bed-days for hospitalized patients [9].

Acute gastroenteritis in the community is usually self-limiting. However, at times, its diagnoses may be complicated and the prescribers may be misled by the diagnoses. Shigellosis infection, for instance, may lead to a life-threatening complication if not correctly diagnosed and quickly treated. Hydration therapy is the key treatment here. Then, antibiotic treatment is also indicated for specific bacterial infection where the identification of an etiological agent by bacterial stool culture is rare $[10,11]$. Careless use of antibiotics in hospitals can actually trigger another type of diarrhea (antibiotic-associated diarrhea). This type of diarrhea is caused by bacterial species, one of which is Clostridium difficile. This situation requires another treatment using different antibiotics since some of the bacterial species are resistant to many of the easily available antibiotics.

The aim of the first phase of the study was to describe the number of antibiotics used in a pediatric ward in 2016. Meanwhile, the aim of the second phase was to closely observe antibiotics used for diarrhea treatment in children between May 2017 and December 2017 preceded with stool tests to confirm the etiology.

\section{METHODS}

The study was conducted at Bangil Regional Public Hospital, which is a secondary care hospital with 272 beds. The research method used in the study was a descriptive, observational cross-sectional study. The data were collected based on the two types of medical records. The first type of data was retrospective medical records of the patients in the Pediatric Ward of Bangil Regional Public Hospital in 2016. The second type of data was drawn from the prospective medical records of the patients including microbiology examination and bacteria sensitivity test of the patients admitted to the hospital between May 2017 and December 2017. The study was granted ethical clearance by the Health Research Ethics Committee of Politeknik Kesehatan Kemenkes Surabaya, Ministry of Health No. 025/S/KEPK/V/2017. The antibiotic use was measured as DDD, days of therapy (DOT), and prescribed 
daily dose (PDD). The function of the DDD is to estimate the use of antibiotics in hospitals drawn from the total number of grams of each antibiotic dispensed during a period of interest divided by the World Health Organization (WHO) - DDD. DOT is the total number of days during which any unit of a specific antimicrobial agent is administered to a particular patient (numerator) divided by the number of patients (denominator) [12-14]. PDD is the average dose administered based on the total sum of prescriptions. The diagnosis data from medical records and antibiotic use were analyzed descriptively. The equation used to calculate DDD per 100 bed-days was modified from DDD/1000 population/day $[15,16]$ as stated in the following equation:

$\mathrm{DDD} / 1000$ population $/$ day $=\frac{\text { Amount usedin } 1 \text { year }(\mathrm{mg}) \times 1000}{\mathrm{DDD}(\mathrm{mg}) \times \text { population } / 365(\text { days })}$

Several adjustments were made in terms of the DDD of a specific period and hospital bed-days of care availability derived from the inpatient's days of care to the equation. The DDD was drawn from the assumed average maintenance of dose per day on a drug used for the WHO-based DDD main indication in adults.

The study focused on the analysis of Pearson correlation of the number of patients and the number of antibiotics used. The absolute values of $r$ at $0-0.19$ represented very weak, $0.2-0.39$ weak, $0.40-0.59$ moderate, 0.6-0.79 strong, and 0.8-1 very strong associations or correlations. The significant difference between the average duration of the stay of patients with antibiotics and that of patients without antibiotics was determined by independent $\mathrm{t}$-tests.

\section{RESULTS}

More than $65 \%$ of the children were admitted to the hospital due to infectious disorders and diarrhea was the second most common disorder. Not all children with infectious disorders were treated with antibiotics. Only 56\% of the children admitted to the hospital in 2016 (Table 1) and $29 \%$ of the children with diarrhea admitted to the hospital between May and December 2017 were treated with antibiotics (Table 2).

The average DDD per 100 bed-days in 2016 was 45.57 (the result of the difference between 23.18 and 69.95) as shown in Table 3. The Pearson correlation between the number of patients and the DDD per 100 bed-days was weak (0.4). The average DDD for children with diarrhea between May 2017 and December 2017 was 12.1 as shown in Table 4. The DOT for ampicillin of 14 days/4 patients was 3.5 and the DOT for metronidazole of 6 days $/ 2$ patients was 3 . The PDD for ampicillin of $11.5 \mathrm{~g} / 14$ days was $0.8 \mathrm{~g}$ and the PDD for metronidazole of $1175 \mathrm{~g} / 6$ days was $0.2 \mathrm{~g}$.

The etiology of $48 \%$ of the hospitalized children with diarrhea was Escherichia coli (Table 5). There were zero E. coli isolates sensitive to ampicillin. The average duration of stay of the hospitalized children with diarrhea treated with antibiotics was similar to that of the hospitalized children with diarrhea treated without antibiotics ( $p>0.05$ ).

\section{DISCUSSION}

In developing countries, infectious disorders in respiratory and digestive system, predominantly pneumonia, and gastroenteritis ranging between $45 \%$ and $80 \%$ account for the most frequent reasons for children's hospitalization [17-21]. Antibiotics are indicated particularly for below 5-year-old children with pneumonia, bronchiolitis, and urinary tract infection. Consequently, there is a high DOT of antibiotics prescribed for hospitalized children [22]. The lower DDD per 100 beddays is attributed to the lower DDD in comparison to the number of patients with diarrhea diagnosis. The DDD is the assumed average maintenance dose per day for a drug mainly prescribed for adults. Apart from its effectiveness, antibiotics also carry a microbial resistance risk. Unnecessary antibiotic prescription is the most common sign of inappropriate antibiotic use [23-27].
Table 1: The number of patients in pediatric ward in 2016

\begin{tabular}{llll}
\hline \multirow{2}{*}{ Month } & \multicolumn{2}{l}{ Number of patients } & \multirow{2}{*}{ Total (\%) } \\
\cline { 2 - 3 } & $\begin{array}{l}\text { With } \\
\text { antibiotic (\%) }\end{array}$ & $\begin{array}{l}\text { Without } \\
\text { antibiotic (\%) }\end{array}$ & \\
\hline January & $74(8.94)$ & $72(11.11)$ & $146(9.89)$ \\
February & $58(7.01)$ & $57(8.80)$ & $115(7.79)$ \\
March & $70(8.45)$ & $70(10.80)$ & $140(9.49)$ \\
April & $70(8.45)$ & $48(7.41)$ & $118(7.99)$ \\
May & $95(11.48)$ & $90(13.89)$ & $185(12.53)$ \\
June & $79(9.54)$ & $39(6.02)$ & $118(7.99)$ \\
July & $38(4.59)$ & $53(8.18)$ & $91(6.17)$ \\
August & $79(9.54)$ & $66(10.18)$ & $145(9.82)$ \\
September & $51(6.16)$ & $39(6.02)$ & $90(6.10)$ \\
October & $80(9.66)$ & $40(6.17)$ & $120(8.13)$ \\
November & $79(9.54)$ & $34(5.25)$ & $113(7.66)$ \\
December & $55(6.64)$ & $40(6.17)$ & $95(6.44)$ \\
Total & $828(56.10)$ & $648(43.90)$ & $1476(100)$ \\
\hline
\end{tabular}

Table 2: The number of patients in pediatric ward between May 2017 and December 2017

\begin{tabular}{llll}
\hline \multirow{2}{*}{ Age (years) } & \multicolumn{2}{l}{ Number of patients } & \multirow{2}{*}{ Total (\%) } \\
\cline { 2 - 3 } & $\begin{array}{l}\text { With } \\
\text { antibiotic (\%) }\end{array}$ & $\begin{array}{l}\text { Without } \\
\text { antibiotic (\%) }\end{array}$ \\
\hline$<1$ & $4(19.05)$ & $7(33.33)$ & $11(52.38)$ \\
$1-<5$ & $2(9.52)$ & $7(33.33)$ & $9(42.86)$ \\
$5-14$ & - & $1(4.76)$ & $1(4.76)$ \\
Total & $6(28.57)$ & $15(71.43)$ & $21(100)$ \\
\hline
\end{tabular}

Table 3: Defined daily dose per 100 bed-days in a pediatric ward in 2016

\begin{tabular}{|c|c|c|c|}
\hline Antibiotic name & $\begin{array}{l}\text { ATC } \\
\text { code }\end{array}$ & $\begin{array}{l}\text { DDD } \\
\text { standard }\end{array}$ & $\begin{array}{l}\text { DDD per } 100 \\
\text { bed-days }\end{array}$ \\
\hline \multicolumn{4}{|c|}{ Oral route of drug administration } \\
\hline Chloramphenicol & J01BA01 & 3 & 1.24 \\
\hline Thiamphenicol & J01BA02 & 1.5 & 3.30 \\
\hline Amoxicillin & J01CA04 & 1 & 6.79 \\
\hline Amoxicillin/clavulanic acid & J01CR02 & 1 & 0.17 \\
\hline Cefadroxil & J01DB05 & 2 & 0.68 \\
\hline Cefixime & J01DD08 & 0.4 & 2.09 \\
\hline Azithromycin & J01FA10 & 0.3 & 2.73 \\
\hline Erythromycin & J01FA01 & 1 & 0.72 \\
\hline Spiramycin & J01FA02 & 3 & 0.01 \\
\hline Rifampicin & $\mathrm{J} 04 \mathrm{AB} 02$ & 0.6 & 3.83 \\
\hline Ethambutol & J04AK02 & 1.2 & 0.59 \\
\hline Pyrazinamide & J04AK01 & 1.5 & 2.65 \\
\hline Total & & & 24.87 \\
\hline \multicolumn{4}{|c|}{ Parenteral route of drug administration } \\
\hline Chloramphenicol & J01BA01 & 3 & 2.18 \\
\hline Ampicillin & J01CA01 & 2 & 9.09 \\
\hline Amoxicillin & J01CA04 & 1 & 1.65 \\
\hline Ampicillin/sulbactam & J01CR01 & 6 & 2.04 \\
\hline Cefazolin & J01DB04 & 3 & 0.02 \\
\hline Cefuroxime & J01DC02 & 3 & 0.02 \\
\hline Cefotaxime & J01DD01 & 4 & 0.24 \\
\hline Ceftazidime & J01DD02 & 4 & 0.39 \\
\hline Ceftriaxone & J01DD04 & 2 & 3.53 \\
\hline Streptomycin & J01GA01 & 1 & 0.08 \\
\hline Gentamicin & J01GB03 & 0.24 & 0.51 \\
\hline Amikacin & J01GB06 & 1 & 0.04 \\
\hline Metronidazole & J01XD01 & 1.5 & 0.96 \\
\hline Total & & & 20.77 \\
\hline \multicolumn{3}{|c|}{$\begin{array}{l}\text { Total of oral and parenteral routes of drug } \\
\text { administration }\end{array}$} & 45.57 \\
\hline
\end{tabular}

DDD: Defined daily dose, ATC: Anatomical therapeutic chemical 
Table 4: The prescribed antibiotics for children with diarrhea between May 2017 and December 2017

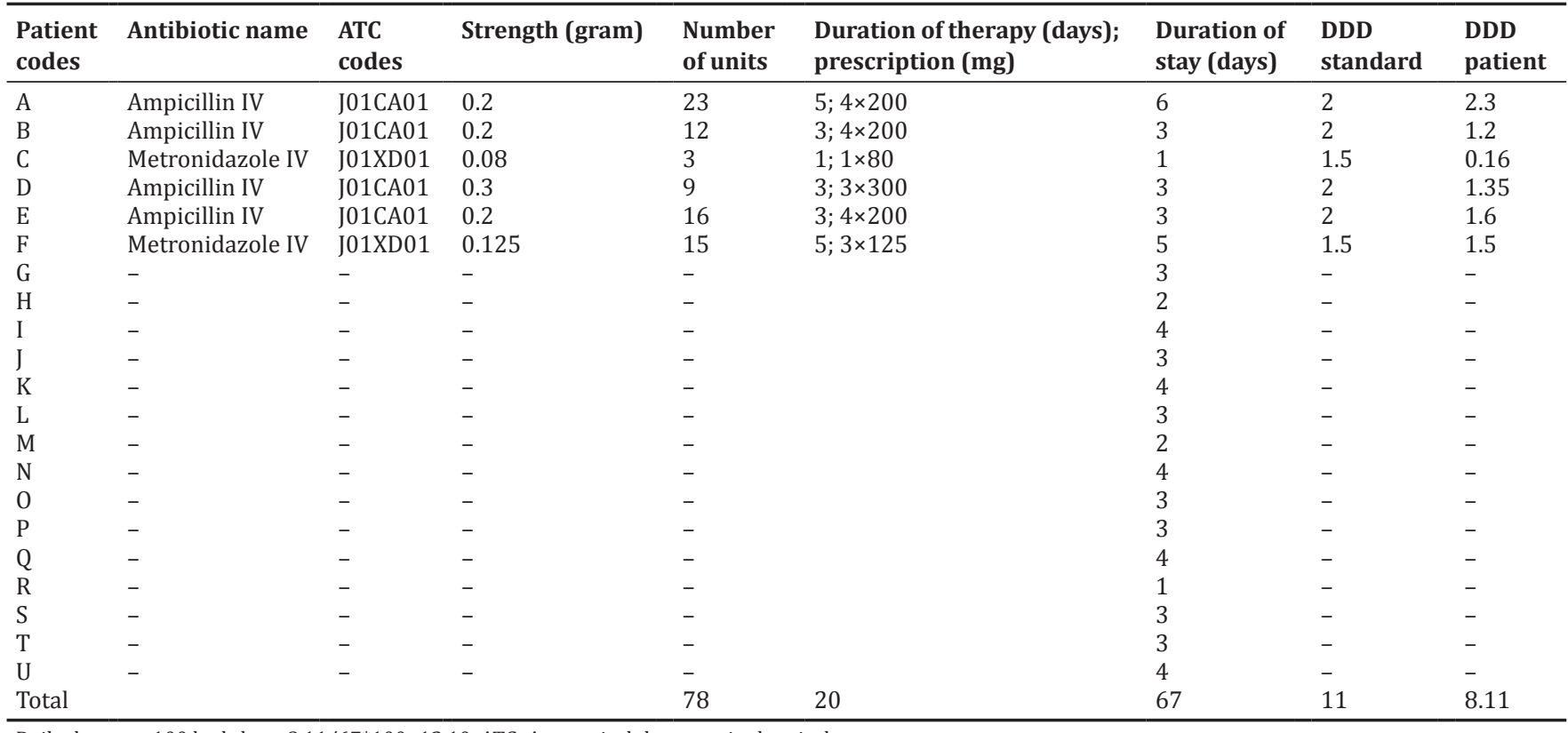

Daily dose per 100 bed-days: $8.11 / 67^{*} 100=12.10$. ATC: Anatomical therapeutic chemical

Table 5: The isolation of bacteria from each patient's stool test between May 2017 and December 2017

\begin{tabular}{|c|c|c|c|}
\hline \multirow[t]{2}{*}{ Bacteria } & \multicolumn{2}{|c|}{ Number of isolates in } & \multirow[t]{2}{*}{ Total (\%) } \\
\hline & $\begin{array}{l}\text { Patient with } \\
\text { antibiotic (\%) }\end{array}$ & $\begin{array}{l}\text { Patient without } \\
\text { antibiotic (\%) }\end{array}$ & \\
\hline Escherichia coli & $3(14.29)$ & $7(33.33)$ & $10(47.62)$ \\
\hline $\begin{array}{l}\text { Serratia } \\
\text { odorifera }\end{array}$ & $1(4.76)$ & 7 (33.33) & $8(38.09)$ \\
\hline $\begin{array}{l}\text { Burkholderia } \\
\text { cepacia }\end{array}$ & $1(4.76)$ & $1(4.76)$ & $2(9.52)$ \\
\hline $\begin{array}{l}\text { Pseudomonas } \\
\text { aeruginosa }\end{array}$ & $1(4.76)$ & - & $1(4.77)$ \\
\hline Total & $6(28.57)$ & 15 (71.43) & $21(100)$ \\
\hline
\end{tabular}

Antibiotics should not be carelessly prescribed for acute gastroenteritis since the misuse of antibiotics contributes to antibiotic resistance, one of which is Clostridium difficile infection. According to the Clinical Practice Guidelines of Health Service Facilities (FASYANKES) of the Ministry of Health No. 514/2015, acute gastroenteritis can be treated in the following ways [28]. First, Shigella gastroenteritis is treated with ampicillin and trimethoprim-sulfamethoxazole. Then, metronidazole is prescribed if there have been trophozoites of Entamoeba histolytica within red blood cells, or if there have been trophozoites or cysts of Giardia seen in the feces. Metronidazole can also be considered for persistent diarrhea with blood in the stool when two different antibiotics usually locally effective for Shigella have been prescribed without any clinical improvements. Finally, parenteral antibiotic therapy is recommended for bacteremia (systemic infections) triggered by bacterial enteric pathogens [29-31]. Doctors generally refrain from prescribing ciprofloxacin for children though it is effective in the treatment of pathogenic E. coli $[32,33]$. In the study, the etiology of acute diarrhea is E. coli (10 specimens; $47.62 \%$ ), Serratia odorifera (eight specimens; 38.09\%), Burkholderia cepacia (two specimens; 9.52\%), and Pseudomonas aeruginosa (one specimen; $4.77 \%$ ). Ampicillin and metronidazole were not recommended for these 21 patients. The sensitivity of E. coli to ampicillin is low [34-36]. Interestingly, the average length of the stay of inpatients with antibiotic treatment is similar to that of inpatients without antibiotic treatment.

\section{CONCLUSION AND RECOMMENDATION}

Surveillance is mandatory since it is one of the assessment criteria of hospital accreditation and this surveillance extends to the proper use of the antibiotics in the hospital $[37,38]$. The improper use of antibiotics was, in fact, still detected in the daily routines of the hospital, such as in monitoring drug therapy or medication therapy management using Gyssen flowchart [24]. The average DDD per 100 bed-days was significantly lower than the percentage of the infectious disorder. This study shows that the antibiotic use in children with diarrhea is not appropriate. Meanwhile, ampicillin and metronidazole were not prescribed for the patients due to several reasons. First, infectious diarrhea by $E$. coli is usually self-limiting and has low ampicillin effectiveness against $E$. coli. Second, there were no indications of Trichomonas vaginalis, amebiasis, or giardiasis from the stool culture. Further studies of other infectious disorders are recommended to evaluate whether discrepancies between the number of antibiotics prescribed and the number of antibiotics suggested by the therapeutic guidelines exist.

\section{ACKNOWLEDGMENTS}

The research was a joint study conducted under the Memorandum of Understanding between the Faculty of Pharmacy of the University of Surabaya in Surabaya and the Bangil Regional Public Hospital in Pasuruan. The authors thank the hospital management and staff for their cooperation to collect the data from the patients and to use them for the evaluation.

\section{AUTHORSHIP AND CONTRIBUTORSHIP STATEMENT}

FH and MSM collected and calculated the data. FH, MSM, and RY analyzed and interpreted the data. FH, RY, and RA wrote the manuscript. All authors read and approved the final manuscript.

\section{CONFLICTS OF INTEREST STATEMENT}

The authors declare that there are no conflicts of interest.

\section{REFERENCES}

1. Magill SS, Edwards JR, Bamberg W, Beldavs ZG, Dumyati G, Kainer MA, et al. Multistate point-prevalence survey of health care associated infections. N Engl J Med 2014;370:1198-208. 
2. Ling ML, Apisarnthanarak A, Madriaga G. The burden of healthcareassociated infections in Southeast Asia: A systematic literature review and meta-analysis. Clin Infect Dis 2015;60:1690-9.

3. Duerink DO, Roeshadi D, Wahjono H, Lestari ES, Hadi U, Wille JC, et al. Surveillance of healthcare-associated infections in Indonesian hospitals. J Hosp Infect 2006;62:219-29.

4. Herawati F, Hartono ID, Pranajaya D, Narindra IP. Antibiotic use at primary healthcare centers in Surabaya: A surveillance study. Int J Pharm Pharm Sci 2017;9:41-4.

5. Muslim Z. Antibiotic prescription to pediatric in hospital Bengkulu, Indonesia: ATC/DDD index. Int J Pharm Pharm Sci 2018;10:31-4.

6. Hanafi EM, Danial EN. Natural antimicrobials in the pipeline and possible synergism with antibiotics to overcome microbial resistance. Asian J Pharm Clin Res 2019;12:15-21.

7. Suman RK, Ray IM, Mohanty NC, Mukhia RK, Deshmukh YA. Assessment of usage of antibiotic and their pattern of antibiotic sensitivity test among childhood fever. Int J Pharm Pharm Sci 2014;6:296-9. Available from: https://www.innovareacademics.in/ journals/index.php/ijpps/article/view/1790

8. Niranjana ES, Sambath KR, Sudha M, Venkateswaramurthy N. Review on clinically developing antibiotics. Int J App Pharm 2018;10:13-8.

9. National Action Plan on antibiotics in human healthcare: Three measurable goals for a reduction of antibiotic consumption towards 2020. Denmark: The Danish Ministry of Health; 2017.

10. Murni IK, Duke T, Kinney S, Daley AJ, Soenarto Y. Reducing hospitalacquired infections and improving the rational use of antibiotics in a developing country: An effectiveness study. Arch Dis Child 2015;100:454-9.

11. World Health Organization. Antimicrobial resistance: Global report on surveillance. Geneva: World Health Organization; 2014|. Available from: http://www.who.int/iris/handle/10665/112642.

12. Fridkin SK, Srinivasan A. Implementing a strategy for monitoring inpatient antimicrobial use among hospitals in the United States. Clin Infect Dis 2014;58:401-6.

13. Centers for Disease Control and Prevention. Antimicrobial Use and Resistance (AUR) Module. Available from: https://www.cdc.gov/ nhsn/PDFs/pscManual/11pscAURcurrent.pdf. [Last accessed on 2015 Jan 28].

14. Indonesian Ministry of Health (IMOH). Pedoman Umum Penggunaan Antibiotik. Jakarta, Indonesia: Indonesian Ministry of Health; 2011. Available from: http://www.binfar.depkes.go.id/dat/Permenkes Antibiotik.pdf. [Last accessed on 2018 Jul 26].

15. ATC/DDD Index 2017. Date Unknown. Available from: https://www. whocc.no/atc ddd index. [Last accessed on 2018 Jul 26].

16. WHO International Working Group for Drug Statistics Methodology, WHO Collaborating Centre for Drug Statistics Methodology and WHO Collaborating Centre for Drug Utilization Research and Clinical Pharmacological Services. Introduction to Drug Utilization Research. Geneva: World Health Organization; 2003

17. Sidik NA, Lazuardi L, Agung FH, Pritasari K, Roespandi H, Setiawan T, et al. Assessment of the quality of hospital care for children in Indonesia. Trop Med Int Health 2013;18:407-15.

18. Agency for Healthcare Research and Quality (AHRQ), Center for Delivery, Organization, and Markets, Healthcare Cost and Utilization Project (HCUP). Kids' Inpatient Database (KID), 2012. Available from: https://www.hcup-us.ahrq.gov/kidoverview.jsp. [Last accessed on 2015 Jan 28].

19. Leyenaar JK, Shieh MS, Lagu T, Pekow PS, Lindenauer PK Direct admission to hospitals among children in the United States. JAMA Pediatr 2015;169:500-2.

20. Barwise-Munro R, Al-Mahtot M, Turner S. Mortality and other outcomes after paediatric hospital admission on the weekend compared to weekday. PLoS One 2018;13:e0197494.

21. Chaw PS, Schlinkmann KM, Raupach-Rosin H, Karch A, Pletz MW,
Huebner $\mathrm{J}$, et al. Antibiotic use on paediatric inpatients in a teaching hospital in the Gambia, a retrospective study. Antimicrob Resist Infect Control 2018;7:82.

22. Momattin H, Al-Ali AY, Mohammed K, Al-Tawfiq JA. Benchmarking of antibiotic usage: An adjustment to reflect antibiotic stewardship program outcome in a hospital in Saudi Arabia. J Infect Public Health 2018;11:310-3

23. Ergül AB, Gökçek İ, Çelik T, Torun YA. Assessment of inappropriate antibiotic use in pediatric patients: Point-prevalence study. Turk Pediatri Ars 2018;53:17-23.

24. Hadi U, Duerink DO, Lestari ES, Nagelkerke NJ, Keuter M, Huis In't Veld D, et al. Audit of antibiotic prescribing in two governmental teaching hospitals in Indonesia. Clin Microbiol Infect 2008;14:698-707.

25. Herawati F, Yulia R, Hak E, Hartono AH, Michiels T, Woerdenbag HJ, et al. A retrospective surveillance of the antibiotics prophylactic use of surgical procedures in private hospitals in Indonesia. Hospital Pharmacy, SAGE; 2018. p. 1-7.

26. Yulia R, Giovanny BE, Khansa AA, Utami SP, Alkindi FF, Herawati $\mathrm{F}$, et al. The third-generation cephalosporin use in a regional general hospital in Indonesia. Int Res J Pharm 2018;9:41-5.

27. Herawati F, Rahem A, Handayani D, Yulia R. Antibiotic prophylactics on curettage for preventing pelvic inflammatory disease events: Is it necessary? Asian J Pharm Clin Res 2018;11:267-9.

28. Indonesian Ministry of Health (IMOH). Keputusan Menteri Kesehatan Republik Indonesia Nomor HK.02.02/MENKES/514/2015 Tentang Panduan Praktik Klinis Bagi Dokter Di Fasilitas Pelayanan Kesehatan Tingkat Pertama. Jakarta, Indonesia: Indonesian Ministry of Health; 2015. Available from: https://www.draguscn.com/wp-content/ uploads/2018/02/kmk-514-2015-ppk-faskes-primer1.pdf.

29. World Health Organization. World Health Report 2013: Research for Universal Health Coverage. Geneva: World Health Organization; 2013! Available from: http://www.who.int/iris/handle/10665/85761. [Last accessed on 2015 Jan 28].

30. Centers for Disease Control and Prevention Office of Infectious Disease. Antibiotic Resistance Threats in the United States, 2013. Available from: http://www.cdc.gov/drugresistance/threat-report-2013. [Last accessed on 2015 Jan 28].

31. Ventola CL. The antibiotic resistance crisis: Part 1: Causes and threats. P T 2015;40:277-83.

32. Chaudhry N, Mukherjee TK. Differential effects of temperature and ph on the antibiotic resistance of pathogenic and non-pathogenic strains of Escherichia coli. Int J Pharm Pharm Sci 2016;8:146-9.

33. Okoye NV, Oyawole MR, Uzochukwu PU, Oyetunde OO. Review of ciprofloxacin use in children. Nig Q J Hosp Med 2013;23:43-7.

34. Makvana S, Krilov LR. Escherichia coli infections. Pediatr Rev 2015;36:167-71

35. Zhou Y, Zhu X, Hou H, Lu Y, Yu J, Mao L, et al. Characteristics of diarrheagenic Escherichia coli among children under 5 years of age with acute diarrhea: A hospital based study. BMC Infect Dis 2018;18:63-72.

36. Amaya E, Reyes D, Vilchez S, Paniagua M, Möllby R, Nord CE, et al. Antibiotic resistance patterns of intestinal Escherichia coli isolates from Nicaraguan children. J Med Microbiol 2011;60:216-22.

37. Doron S, Davidson LE. Antimicrobial stewardship. Mayo Clin Proc 2011;86:1113-23.

38. Indonesian Ministry of Health (IMOH). Peraturan Menteri Kesehatan Republik Indonesia Nomor 8 tahun 2015 Tentang Program Pengendalian Resistensi Antimikroba Di Rumah Sakit. Jakarta, Indonesia: Indonesian Ministry of Health; 2015. Available from: https:/www.google.com/ url $2 \mathrm{sa}=\mathrm{t} \& \mathrm{rct}=\mathrm{j} \& \mathrm{q}=\&$ esrc $=\mathrm{s} \&$ source $=$ web $\& \mathrm{~cd}=2 \& \mathrm{cad}=\mathrm{rja} \&$ uact $=8 \&$ ved=2ahUKEwjQu6eW163dAhUKuo8KHXM2COYQFjABeg QICBA B\&url=http $\% 3 \mathrm{~A} \% 2 \mathrm{~F} \% 2$ Fperaturango.id $\% 2$ Fpermen $\% 2 \mathrm{Fkem}$ enkes- nomor-8-tahun-2015. html\&usg=AOvVaw3Je9LBJhw8zJiB C1es7TNO. 